\title{
Tropical phytoplankton community development in mesocosms inoculated with different life stages
}

\author{
Karolina Härnström ${ }^{1, *}$, Anna Godhe ${ }^{1}$, V. Saravanan ${ }^{2}$, Indrani Karunasagar ${ }^{2}$, \\ Iddya Karunasagar ${ }^{2}$, Ann-Sofi Rehnstam-Holm ${ }^{3}$ \\ ${ }^{1}$ Department of Marine Ecology, Marine Botany, Göteborg University, PO Box 461, 40530 Göteborg, Sweden \\ ${ }^{2}$ Department of Fishery Microbiology, College of Fisheries, Karnataka Veterinary Animal and Fisheries Sciences University, \\ PO Box 527, Mangalore 575 002, India \\ ${ }^{3}$ Institution of Mathematics and Natural Sciences, Kristianstad University, 29188 Kristianstad, Sweden
}

\begin{abstract}
Many diatom species have the ability to form benthic resting stages, but the importance of these stages as a supply for planktonic blooms is uncertain. A mesocosm study was carried out in December 2005 to January 2006 in Mangalore, India. Mesocosms were inoculated with various combinations of benthic and/or planktonic cells, sampled from the coastal SE Arabian Sea, and the development of the planktonic community was followed. Diatoms dominated the phytoplankton community in all mesocosms, irrespective of inoculum. The most significant differences among inoculum types were altered species composition, and the timings of the maximum cell abundances, which lagged behind in the sediment mesocosms. Populations of Thalassiosira were initiated by both plankton and benthic propagules. Taxa known from temperate coastal areas to seed bloom by benthic propagules, such as Chaetoceros and Skeletonema, were predominantly seeded by planktonic cells in this experiment; this implies differential seeding strategy within the same species at different latitudes. The species assemblage encountered in the plankton and sediment was similar, which indicates that the benthic resting stages seed an autochthonous phytoplankton flora in the area. High species diversity in all inoculated mesocosms was maintained throughout the experimental period, although the actual number of species was fewer at the end. The hydrographic conditions and timing of formation, survival, and germination of diatom resting stages in SE Arabian Sea are discussed.
\end{abstract}

KEY WORDS: Benthic resting stages $\cdot$ Mesocosm $\cdot$ Arabian Sea $\cdot$ Phytoplankton $\cdot$ Community development

\section{INTRODUCTION}

Many phytoplankton groups have benthic resting stages, formed asexually or sexually. These stages are commonly known to provide short- or long-term survival, and may also contribute to natural dispersal by currents or when transported in ballast water tanks (Hallegraeff \& Bolch 1992). The recruitment of vegetative cells into the water column from resting stages is most probably preceded by resuspension of bottom sediment. The potential of bloom initiation from resting stages is poorly examined, but a growing number of scientists have highlighted the importance of benthic life stages in terms of function and influence on water column dynamics (e.g. Raffaelli et al. 2003). After the ger- mination, growth of cells is controlled by a number of different factors, such as temperature, light intensity, nutrient concentration, inter- and intraspecific competition, and predation (Ishikawa \& Furuya 2004). Supplementary understanding of algal dynamics and life cycles, as well as knowledge of different environmental factors regulating algal growth and blooms, is necessary for more precise predictions of algal bloom events.

Some diatom species form benthic resting stages during their life cycle. Formation of diatom resting stages is usually initiated by adverse conditions, like nutrient and light depletion, changes in salinity, or mechanical stress (Hargraves \& French 1983, Sicko-Goad et al. 1989). Hence, to avoid the poor conditions in the water column, they sink to the bottom of the sea. There 
they can remain viable for long periods (McQuoid et al. 2002), and can occasionally seed blooms (McQuoid \& Godhe 2004). Diatoms have different kinds of resting stages, such as spores (hypnospores), resting cells, and winter stages, but the ecological significance of the different stages is uncertain (Garrison 1981). The resting stages are formed by mitosis, with or without cytokinesis and attendant valves involved. The process is usually asexual, but there are exceptions with spores originating from sexual auxospores (McQuoid \& Hobson 1996). Resting spores differ from vegetative cells in physiology and morphology, while resting cells are morphologically similar to the vegetative cells, but with physiological and cytoplasmic differences (McQuoid \& Hobson 1996). We hereafter refer to these various types as resting stages.

A record of a specific species in a given area is preceded by any of the following: advection of the species from a neighboring area, growth of hidden flora, or resuspension and subsequent germination of resting stages. Frontal systems provide the physical facilities for vegetative cells to settle and function as potential propagules (Smayda 2002). It is possible that exponentially growing cells transported into the surface waters of an area immediately result in a large population (Godhe et al. 2002a). Some vegetative cells may survive stress in the given area, and these 'fugitive cells' (Kilham \& Kilham 1980) can grow and accumulate once favorable conditions are re-established (Backhaus et al. 1999, 2003). Benthic resting stages may also act as an important inoculation source for initiating planktonic blooms. This phenomenon is known from neritic regions, in which accumulation areas of resting stages are present. From there they can be brought up to the surface water triggered by currents or upwelling (Tommasa et al. 2000).

In India, little work has focused on resting stages. Various dinoflagellate cysts have been detected from the SW Indian coast (Godhe et al. 2000, 2002b). In general, the tropics have a low density of dinoflagellate resting cysts compared to temperate waters, but on the other hand the diversity is higher (Godhe et al. 2000). Previously published information on the quantity and diversity of other phytoplankton resting stages in the coastal sediment of the SE coastal Arabian Sea is, as far as we know, not available.

The aim of this mesocosm study, carried out in Mangalore, India, was to observe and compare the growth and species composition of tropical diatom phytoplankton assemblages seeded with different life stages. In previous studies, mesocosms have proven to be well suited for large-scale studies in many different environments (e.g. Brussaard et al. 2005). They enable replication, allow control of the examined system, and preserve natural conditions relatively well.

\section{MATERIALS AND METHODS}

Study site. Water surface temperature in the coastal Arabian Sea ranges from 26 to $30^{\circ} \mathrm{C}$ all year round, and salinity from 34 to 37 (Ramana et al. 1991). Fluctuations in phytoplankton biomass are small, and dense algal blooms are unusual (Segar \& Hariharan 1989). In general, nitrogen constitutes the limiting nutrient for phytoplankton growth. The average annual ratio of major nutrients $(\mathrm{N}: \mathrm{Si}: \mathrm{P})$ is 7:20:1 (Subrahmanyan \& Sarma 1960). The SW monsoon, which prevails during June to September, induces coastal upwelling, and has a direct influence on the hydrography and productivity along the SW Indian coast. During the SW monsoon, nutrient concentrations rise, and as a consequence, rapid increases in chl a concentrations are recorded (Shenoy \& Patil 2002). Monospecies blooms are only recorded during this time of year (Subrahmanyan \& Sarma 1960). The upwelling generated during the initial stages of the SW monsoon can trigger diatom blooms by resuspension and reintroduce diatom resting stages back into the euphotic zone (Rixen et al. 2000). During post-monsoon, the hydrographic conditions signify overall reduced nutrient concentrations, and a decrease in primary production. $\mathrm{Chl}$ a concentrations in the coastal zone normally reach a maximum of $2 \mu \mathrm{g} \mathrm{l}^{-1}$ during December to February. Diatoms dominate the phytoplankton community and sometimes constitute $>95 \%$ of the total flora (Subrahmanyan 1958, 1959, 1960, Subrahmanyan \& Sarma 1965). Skeletonema costatum and Thalassiosira sp. are the most abundant diatoms during this period (Shenoy \& Patil 2002). In the state of Goa (400 km north of Mangalore), periodic blooms of diatoms have been reported during December and January (D'Souza et al. 2003).

Mesocosms. The mesocosm experiment was carried out at the College of Fisheries, Mangalore, India $\left(12^{\circ} 52^{\prime} \mathrm{N}, 74^{\circ} 53^{\prime} \mathrm{E}\right)$. The experiment ran from December 28,2005 , to January 13,2006 , inside a covered hall. Sediment cores were collected on December 7, 2005, with a gravity corer 35 nautical miles offshore Mangalore, at a water depth of $30 \mathrm{~m}$, and the cores were instantly sampled on the ship. Overlying water was carefully drained and the top 0 to $1 \mathrm{~cm}$ sediment layer was sub-sampled into a plastic jar. The sampled sediment was thereafter kept dark and $\operatorname{cool}\left(4^{\circ} \mathrm{C}\right)$ for $3 \mathrm{wk}$ in order to reduce the numbers of viable vegetative cells. Sea surface phytoplankton were collected from the same location using several net tows $(10 \mu \mathrm{m}$ mesh size), pooled into a $20 \mathrm{l}$ can, and kept in the dark. The chl a concentration of the pooled net samples was estimated (Parsons et al. 1984) immediately upon return to the laboratory and used as a reference value for calculating the volume of inoculum for the mesocosms. 
Seawater (36 PSU) from $10 \mathrm{~km}$ south of Mangalore was ozonated (Ozone Generator-alt 11, Coren) and 9001 were added to each of the 12 light blue cylindrical mesocosms (total volume 2000 l). Three mesocosms served as controls to exclude artefacts. The remaining mesocosms were inoculated with either $2.65 \mathrm{l}$ of the plankton concentrate, $150 \mathrm{ml}$ of the collected sediment, or both, with 3 replicates of each treatment as described below. The inocula were added to the mesocosms in a random order. The mesocosm water was constantly aerated using plastic hoses connected to a pump. Light intensity was $50 \mu \mathrm{mol}$ photons $\mathrm{m}^{-2} \mathrm{~s}^{-1}$ at the water surface, and lamps were switched on during daytime to keep a 12:12 h light:dark cycle. To investigate if suspended matter influenced the light condition, the light penetration at half maximum depth $(30 \mathrm{~cm})$ was compared in plankton versus sediment mesocosms after mixing by stirring every $30 \mathrm{~min}$ for $5 \mathrm{~h}$, by immersing a spherical light meter (Biospherical Instruments, Model QSL2101). A mesocosm pilot study carried out from December 10 to 20, 2005, with identical set-up, revealed low phosphate concentrations $(0.02 \mu \mathrm{M})$. Since phosphate is normally not a limiting factor for natural phytoplankton growth in the area (Krishnakumar \& Bhat 2007), and we wanted to simulate the natural conditions as closely as possible, phosphate was added daily to all 12 mesocosms until normal concentration was reached (i.e. $0.5 \mu \mathrm{M}$, reached on experiment Day 7).

The mesocosms were sampled every 2 to $3 \mathrm{~d}$, until the chl a concentrations were stationary or had declined. Every day the mesocosms were mixed by stirring. During sampling, 2.51 were taken from the mesocosms using a ladle, transferred to black, lightprotected bottles, and immediately processed in the laboratory.

Inocula. The net tows were examined using an inverted light microscope (Zeiss Axiovert 25) to ensure that cells were in a vegetative stage and in good condition. No resting stages were noted in the plankton inoculum. The sediment was analyzed microscopically for resting stages in 2 different ways, using standard procedures for the detection and identification of diatom resting stages (Method 1), and dinoflagellate cysts (Method 2). Method 1: an aliquot of known weight was added to filtered seawater, and subsequently settled in a $10 \mathrm{ml}$ sediment chamber (Utermöhl 1958). Method 2: an aliquot of known weight was sonicated for $5 \mathrm{~min}$ in a Branson 1510 ultrasonic cleaner. Thereafter, the sediment was sieved through a $100 \mu \mathrm{m}$ and a $25 \mu \mathrm{m}$ Retsch stainless steel sieve (diameter $10 \mathrm{~cm}$ ), using filtered seawater. Filtered seawater was added to the sediment captured on the $25 \mu \mathrm{m}$ sieve and settled in a $10 \mathrm{ml}$ sediment chamber. The counts from the 2 methods were pooled together to obtain a total concentration of phytoplankton resting stages (cells g ${ }^{-1}$ wet weight) in the sediment inoculum.

The quantity of plankton inoculum was added to simulate a pre-bloom concentration (ca. $1.0 \mathrm{\mu g} \mathrm{l}^{-1}$ ) of actively growing vegetative cells. After addition of the plankton concentrate, the chl a concentration was estimated to $0.9 \mathrm{\mu g} \mathrm{l}^{-1}$, which corresponds to a low-tomoderate concentration in the area offshore Mangalore (Krishnakumar \& Bhat 2007).

The sediment inoculum was designed to simulate the resuspension of $5 \mathrm{~mm}$ sediment from a seafloor area of $1 \mathrm{~m}^{2}$ and its even distribution through an average water column depth (ca. $30 \mathrm{~m}$ ). To all the mesocosms with sediment inocula, i.e. 3 plankton plus sediment and 3 sediment mesocosms, $150 \mathrm{ml}$ of surface sediment was added.

Parameters analyzed in the mesocosms. Water samples for analyzing environmental variables were collected at each sampling occasion in all 12 mesocosms, i.e. every second or third day. Inorganic nitrate, ammonia, and silicate were analyzed 4 times during the experimental period (December 28, January 2, 6, and 13).

The concentration of inorganic nitrate, ammonia, and silicate were monitored with Merck Spectroquant ${ }^{\circledR}$ kits and quantified in a spectrophotometer (Spectroquant ${ }^{\circledR}$ NOVA 60, Merck). Phosphate concentrations were quantified using the ascorbic acid method, and oxygen by Winkler's titration, according to the Swedish Standardization (SS 028126 Determination of phosphate in water, SS-EN 25831 Determination of dissolved oxygen-Iodometric method, both in Swedish). Temperature, salinity, and $\mathrm{pH}$ were measured using a thermometer, refractometer (Erma), and pH meter (MKVI Systronics), respectively. Total viable bacterial counts (total plate count, TPC) were estimated by the spread plate method (Cook et al. 2000). Total bacterial counts were estimated by DAPI staining of formalin fixed samples $(3 \%)$, following the standard protocols (Porter \& Feig 1980). From each sample, $200 \mathrm{ml}$ was filtered onto GF/F filters for estimations of chl a concentrations. Chlorophyll was extracted in $7 \mathrm{ml}$ of $90 \%$ acetone, and kept in $10 \mathrm{ml}$ tubes overnight at $4{ }^{\circ} \mathrm{C}$. After extraction, $1.5 \mathrm{ml}$ was centrifuged at $4000 \mathrm{rcf}(2000 \times g)$ for $10 \mathrm{~min}$, and thereafter the concentrations were measured on a spectrophotometer (Shimadzu). Chl a calculations were based on equations from Parsons et al. (1984).

A $200 \mathrm{ml}$ subsample was preserved with Lugol's solution for microscopic analysis of phytoplankton and potential grazers in an inverted light microscope at 200 to $400 \times$ magnifications. Samples of 10 or $50 \mathrm{ml}$ were settled in sedimentation chambers (Utermöhl 1958). A minimum of 300 cells was counted in each chamber. Samples from sediment-inoculated mesocosms contained a large amount of inorganic particles, and could therefore only be settled in $10 \mathrm{ml}$ chambers 
in order not to interfere with the phytoplankton species identification and quantification. At least 100 cells were counted in samples with very low cell densities. In cases when this number was not obtained with one single chamber, an additional $10 \mathrm{ml}$ chamber was counted. Only physiologically active vegetative cells were recorded for the total cell count. Especially in the sediment-inoculated mesocosms, empty diatom frustules, or thecae and dinoflagellate cysts were encountered. These were not included in the total cell count.

Species identification was based on Subrahmanyan (1958), Subrahmanyan \& Sarma (1960), Thomsen (1992), Tomas (1997), and Throndsen et al. (2003). Some species belonging to diatom genera such as Pseudo-nitzschia and Skeletonema can be correctly identified only by electron microscopy (Lundholm et al. 2002, Sarno et al. 2005). Identification by light microscopy of some species in other genera, e.g. Thalassiosira, has to rely on examination of acid-cleaned valves mounted in a medium of high refractive index (Hasle \& Syvertsen 1996). Due to the large number of samples and species handled in this study, analysis by electron microscopy, with its specific cleaning and mounting of individual specimens, was unmanageable. Specimens attributed to a particular genus using light microscopy, and belonging to the same morphospecies, were denoted as, e.g., Skeletonema sp., Thalassiosira sp. When 2 unidentified morphospecies of the same genus were detected, they were numerically denoted as, e.g., Pseudo-nitzschia sp. 1 or Pseudonitzschia sp. 2.

Dimensions of all recorded taxa were measured, and biovolumes were calculated using formulas for the geometric shapes closely approximating the taxa (Sun \& Liu 2003).

Calculations and statistics. Comparisons of phytoplankton development among inocula were made with single-factor ANOVA. Time was not included as a factor in the analysis. The comparisons were based on chl a concentrations, biovolumes, or diatom abundances from Days 1 to 17 among the types of inocula. To determine significant comparisons between pairs of inocula, $t$-tests were used. Significance level for the tests was defined as $p<0.05$. To examine if any effects of artefacts existed, single-factor ANOVA, including the controls and all inocula, and pair-wise $t$-tests, including controls and any of the inocula, were performed based on chl a concentration.

Internal gradient analysis was used to trace community changes in the different treatments and to examine the relationships between composition of species and environmental factors. Canonical correspondence analysis (CCA) (CANOCO version 4.5, ter Braak \& Smilauer 2002) was selected as the unimodal response model, since the gradient was more than 2 SDs.
The CCA integrated 13 environmental variables and 47 taxa having over $2 \%$ relative abundance. The type of inoculum for each mesocosm can be represented by nominal variables, but these are not recognized by CANOCO; hence inoculum types were included as 2 dummy variables, 'plankton' and 'sediment', which were coded by 0 for no addition or 1 for addition. None of the data were weighted. CCA was run constrained to each environmental variable in turn to determine the amount of variation that can be accounted for by that variable. Samples for which all environmental data were available (48) were treated as active cases. The remaining samples (48) were treated as supplementary samples. Since CANOCO cannot determine the ordination axes significance, a Monte Carlo test was used to evaluate the significant relationship between environmental and species data. Significance of the CCA axes was tested with 199 permutations.

\section{RESULTS}

\section{Inocula}

Diatoms dominated the plankton inoculum, and the major taxa were Chaetoceros socialis, Cylindrotheca closterium, Dactyliosolen phuketensis, Pseudo-nitzschia sp. 2, Skeletonema sp., Leptocylindrus danicus, Thalassiosira pseudonana, and Thalassionema nitzschioides.

The sediment inoculum contained various diatom resting stages and dinoflagellate cysts, as well as vegetative cells. The major taxa in the sediment inoculum were resting stages of Chaetoceros brevis (6\%), C. didymus (6\%) and Chaetoceros sp. (16\%), Fragilaria sp. (20\%), Thalassiosira pseudonana $(2 \%)$, and Thalassiosira sp. (2\%). Seemingly alive vegetative cells of Actinocyclus ehrenbergii, Odontella mobiliensis, Coscinodiscus radiatus, Coscinodiscus sp. 3, and Pleurosigma sp. were recorded in small numbers (17 to 67 cells of each taxa $\mathrm{g}^{-1}$ wet weight). Dinoflagellate cysts of Diplopsalis sp. (1\%), Oblea sp. (1\%), Protoperidinium avellana $(1 \%)$, P. claudicans $(1 \%)$, Protoperidinium spp. (1\%), Scripsiella trochoidea (25\%), and Spiniferites sp. (11\%) were recorded. The total concentration of diatom resting stages and dinoflagellate cysts was 1050 cells g $^{-1}$ wet weight.

\section{Environmental conditions}

The light condition of the water column of the mesocosms inoculated with only plankton was $88 \%$ of the light provided at the water surface of the mesocosms. Immediately after stirring the sediment-inoculated mesocosm, the light conditions in the water column of 
the mesocosms were $55 \%$. After 1 and $2 \mathrm{~h}$, the light conditions in the water column were 74 and $82 \%$, respectively. By adding sediment, the bottom of the sediment-inoculated mesocosms was darkened. The spherical light-measuring device that we used detects light from all directions. Consequently, the recorded light penetration in the sediment-inoculated mesocosms was, even after $24 \mathrm{~h}$, somewhat lower.

Minor changes in environmental conditions were noticed throughout the experiment, but no significant differences were recorded between the different mesocosms (Table 1). Minimal changes in temperature, $\mathrm{pH}, \mathrm{O}_{2}$, and salinity were observed in all mesocosms. Nitrate and silicate concentrations in the mesocosms fluctuated moderately during the experimental period. The ammonium concentration of the pre-sterilized water increased from $11 \mu \mathrm{M}$ to ca. $40 \mu \mathrm{M}$ in the plankton and plankton-plus-sediment mesocosms, and to ca. $60 \mu \mathrm{M}$ in the sediment and control mesocosms. Phosphate was the fastest consumed inorganic nutrient, and was therefore monitored daily. A steady phosphate concentration of $0.5 \mu \mathrm{M}$ was attained on experiment Day 7 after daily addition. Thereafter no phosphate was added. The increase of the total viable bacteria (TPC) was comparable in all mesocosms. The total bacteria was initially 5- to 7 -fold higher in the sediment-inoculated mesocosms. At the end of the experiment, the sediment-inoculated mesocosms displayed a 2- to 4 -fold higher concentration of bacteria (cells $\mathrm{ml}^{-1}$ ) compared to the control and the plankton mesocosms (Table 1).

\section{Chl $a$, biovolumes, and cell abundances in mesocosms}

The initial chl a concentrations (experiment Day 1) were measured to $0.32-0.82 \mu \mathrm{g} \mathrm{l}^{-1}$ (Fig. 1A). In the
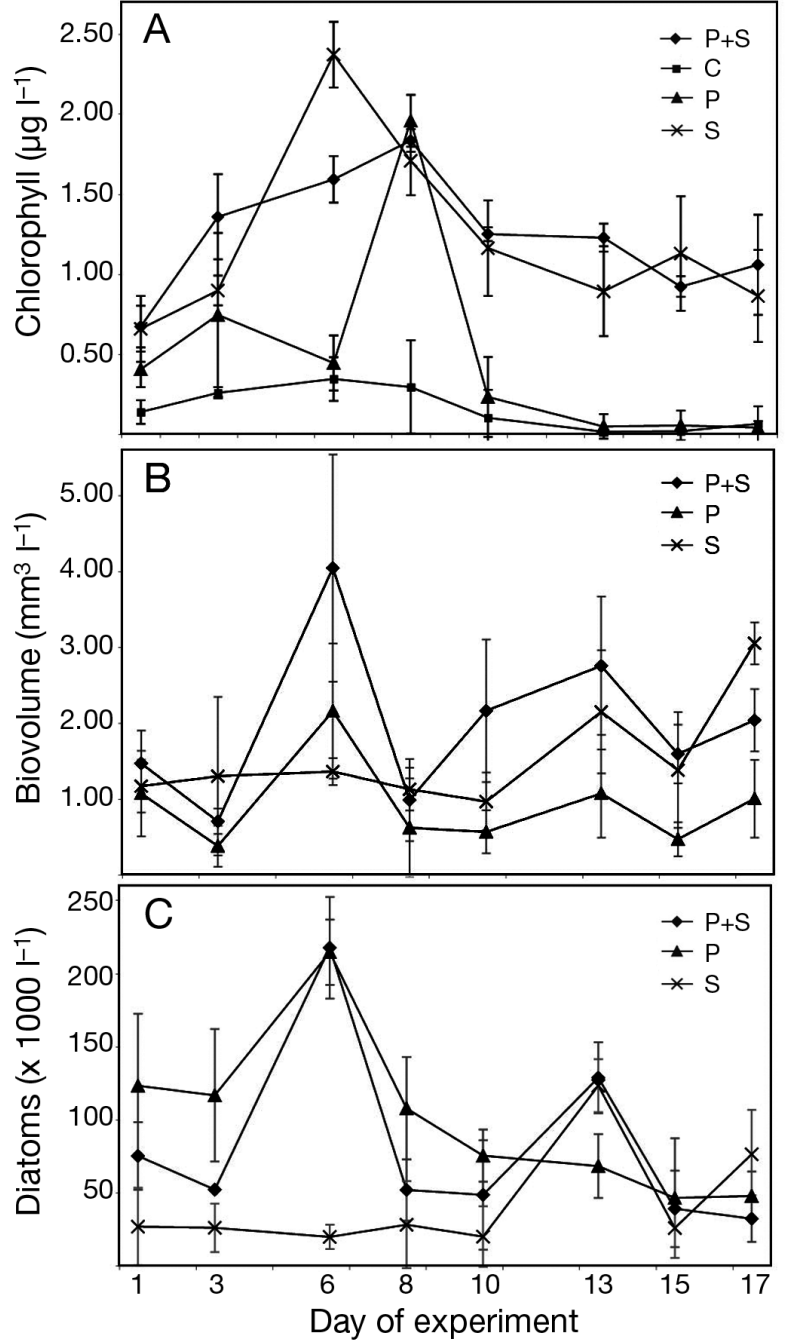

Fig. 1. Growth of phytoplankton population in mesocosm experiment. (A) Chl a concentrations. (B) Biovolumes. (C) Diatom cell abundance. $\mathrm{P}+\mathrm{S}=$ plankton plus sediment, $\mathrm{C}=\mathrm{Con}-$ trol, $\mathrm{P}=$ Plankton, $\mathrm{S}=$ Sediment. $\mathrm{C}$ has been left out in (B) and (C) for clarity. Symbols are mean $\pm \mathrm{SD}(\mathrm{N}=3)$

Table 1. Mean of 3 replicates of environmental variables in the different mesocosms. TPC: total plate count; CFU: colony forming units; $\mathrm{P}+\mathrm{S}$ : plankton plus sediment

\begin{tabular}{|c|c|c|c|c|c|c|c|c|}
\hline \multirow[t]{2}{*}{ Variable } & \multicolumn{2}{|c|}{ Plankton -} & \multicolumn{2}{|c|}{$\longrightarrow \mathrm{P}+\mathrm{S} \longrightarrow$} & \multicolumn{2}{|c|}{$\longrightarrow$ Sediment $\longrightarrow$} & \multicolumn{2}{|c|}{$\longrightarrow$ Control $\longrightarrow$} \\
\hline & Initial & End & Initial & End & Initial & End & Initial & End \\
\hline Salinity (PSU) & 37 & 38 & 35 & 38 & 37 & 37 & 36 & 38 \\
\hline Temperature $\left({ }^{\circ} \mathrm{C}\right)$ & 23 & 22 & 23 & 22 & 23 & 22 & 23 & 22 \\
\hline $\mathrm{pH}$ & 7.87 & 8.00 & 7.86 & 7.96 & 7.89 & 8.00 & 7.92 & 7.98 \\
\hline $\mathrm{O}_{2}\left(\mathrm{ml} \mathrm{l}^{-1}\right)$ & 6.94 & 7.41 & 7.34 & 7.21 & 7.01 & 7.28 & 6.94 & 7.34 \\
\hline $\mathrm{PO}_{4}(\mu \mathrm{M})$ & 0.02 & 0.47 & 0.02 & 0.48 & 0.02 & 0.47 & 0.02 & 0.46 \\
\hline $\mathrm{NH}_{4}(\mu \mathrm{M})$ & 11.11 & 42.59 & 11.11 & 44.44 & 11.11 & 66.67 & 11.11 & 62.96 \\
\hline $\mathrm{NO}_{3}(\mu \mathrm{M})$ & 12.37 & 15.05 & 9.68 & 13.98 & 13.44 & 12.90 & 14.57 & 10.22 \\
\hline $\mathrm{SiO}_{2}(\mu \mathrm{M})$ & 13.82 & 13.60 & 14.78 & 13.68 & 13.55 & 14.74 & 15.18 & 13.90 \\
\hline TPC $\left(\mathrm{CFU} \mathrm{ml} \mathrm{m}^{-1}\right)$ & 1425 & 18000 & 1528 & 12000 & 2477 & 17667 & 520 & 16000 \\
\hline Total bacteria (cells $\mathrm{ml}^{-1}$ ) & 35636 & 106909 & 243514 & 291027 & 207878 & 261260 & 39595 & 77210 \\
\hline Chl a $\left(\mu \mathrm{gl}^{-1}\right)$ & 0.40 & 0.04 & 0.67 & 1.06 & 0.66 & 0.86 & 0.14 & 0.06 \\
\hline
\end{tabular}


plankton mesocosms, initial chl a concentrations were low, but increased until a maximum was reached on Day 8. Thereafter the chl a concentrations declined rapidly. The mesocosms with plankton plus sediment attained a chl a maximum concentration on Day 8 . After Day 8, a moderate decline in chl a concentration followed. In the sediment mesocosms, the maximum chl a concentration was recorded on Day 6. Algal growth was detected in the control mesocosms (Fig. 1A). Contamination could have been introduced by incomplete ozonation of experimental water, insufficient cleaning of the empty mesocosms before the start of the experiment, or cells from the surrounding inoculated mesocosms being transported via aerosols to the controls. Entomoneis sp. was the dominating taxon in the controls, and specimen of this taxon in the inoculated mesocosms might have constituted a contamination. Abundances of Entomoneis sp. were therefore excluded from all statistics.

Since cellular chl a content can vary with light conditions and cell physiology, and cell concentration is often dependent on cell size, i.e. small cells reach higher concentrations than larger cells, we also calculated the changes in biovolumes with time (Fig. 1B). Diatoms dominated the phytoplankton communities in all mesocosms, irrespective of inocula. The graph displaying biovolumes is similar to the diagram of diatom cell abundances (Fig. 1C). The onset of phytoplankton growth in the sediment-inoculated mesocosms lagged behind compared to the mesocosms inoculated with plankton (Fig. 1B,C). The highest biovolumes and diatom abundances in the plankton mesocosms were observed early during the experiment (Day 6), compared to a week later (Day 13) in the sediment mesocosms. Diatom cell abundances in the plankton mesocosms reached a maximum on Day 6 and declined thereafter (Fig. 1C). In the plankton-plus-sediment mesocosms, 2 distinct biovolume and diatom abundance maxima were observed (Fig. 1B,C). The maximum abundance on Day 6 was followed by a smaller peak on Day 13. The sediment mesocosms displayed low biovolumes and diatom abundances during the initial part of the experiment, and did not reach the maximum cell abundance until Day 13.

Control mesocosms were significantly different from any of the inoculated mesocosms based on chl a concentrations ( $p<0.01$, single-factor ANOVA and pair-wise $t$-tests), thus any artefacts could be excluded. Phytoplankton population development in the mesocosms among the types of inocula based on chl a concentrations and biovolumes were significantly different ( $\mathrm{p}<0.05$, single-factor ANOVA). The development of diatom abundances was not significantly different among the 3 inocula types $(p=0.11$, single-factor ANOVA). Based on diatom abundances, pair-wise $t$-tests were significantly different $(\mathrm{p}<0.01)$ between plankton, and plankton-plus-sediment mesocosms, versus sediment mesocosms during the first half of the experiment (Days 1 to 8). Plankton mesocosms were significantly different from planktonplus-sediment and sediment mesocosms ( $\mathrm{p}<0.05$, pair-wise $t$-tests) during the second half of the experiment (Days 10 to 17 ).

\section{Species proportions}

High species diversity was noticed throughout the experiment. The 12 most frequently occurring taxa were present in all the mesocosms, but proportions changed over time depending on type of inocula.

Mesocosms inoculated with plankton only had initially similar proportions of the most common taxa (Fig. 2A). Towards the end of the experiment, Skeletonema tropicum was the dominating species. After Day 6, proportions of Thalassiosira pseudonana and Chaetoceros socialis declined. Thalassiosira sp., Skeletonema sp., and Odontella sp. disappeared on, or shortly after, Day 10.

Plankton-plus-sediment mesocosms had initially a high diversity of species, but were less diverse and dominated by small flagellates at the end of the experiment (Fig. 2B). Skeletonema tropicum, Skeletonema sp., Odontella sp., and Chaetoceros socialis vanished after, or shortly after Day 6. Thalassiosira pseudonana and Thalassiosira sp. maintained a constant proportion of the population throughout the study.

Mesocosms inoculated with sediment only displayed a different community structure. Few of the dominating taxa had large initial relative abundance (Fig. 2C). Thalassiosira pseudonana and Thalassiosira sp. maintained continuous proportions of the species assemblages throughout the experiment, while Chaetoceros socialis disappeared after Day 13. The proportion of Odontella sp. declined during the second half of the study.

\section{Abundances of major diatom species}

Thalassiosira pseudonana was initially most abundant in the plankton mesocosms (Fig. 3A), whereas the abundances were lower in the plankton-plussediment and the sediment mesocosms. After Day 1, it gradually declined in the plankton mesocosms. The highest record of $T$. pseudonana abundance occurred on Day 6 of the experiment in the mesocosms inoculated with plankton plus sediment. A later density peak on Day 13 in the plankton-plus-sediment mesocosms coincided with the highest abundance 

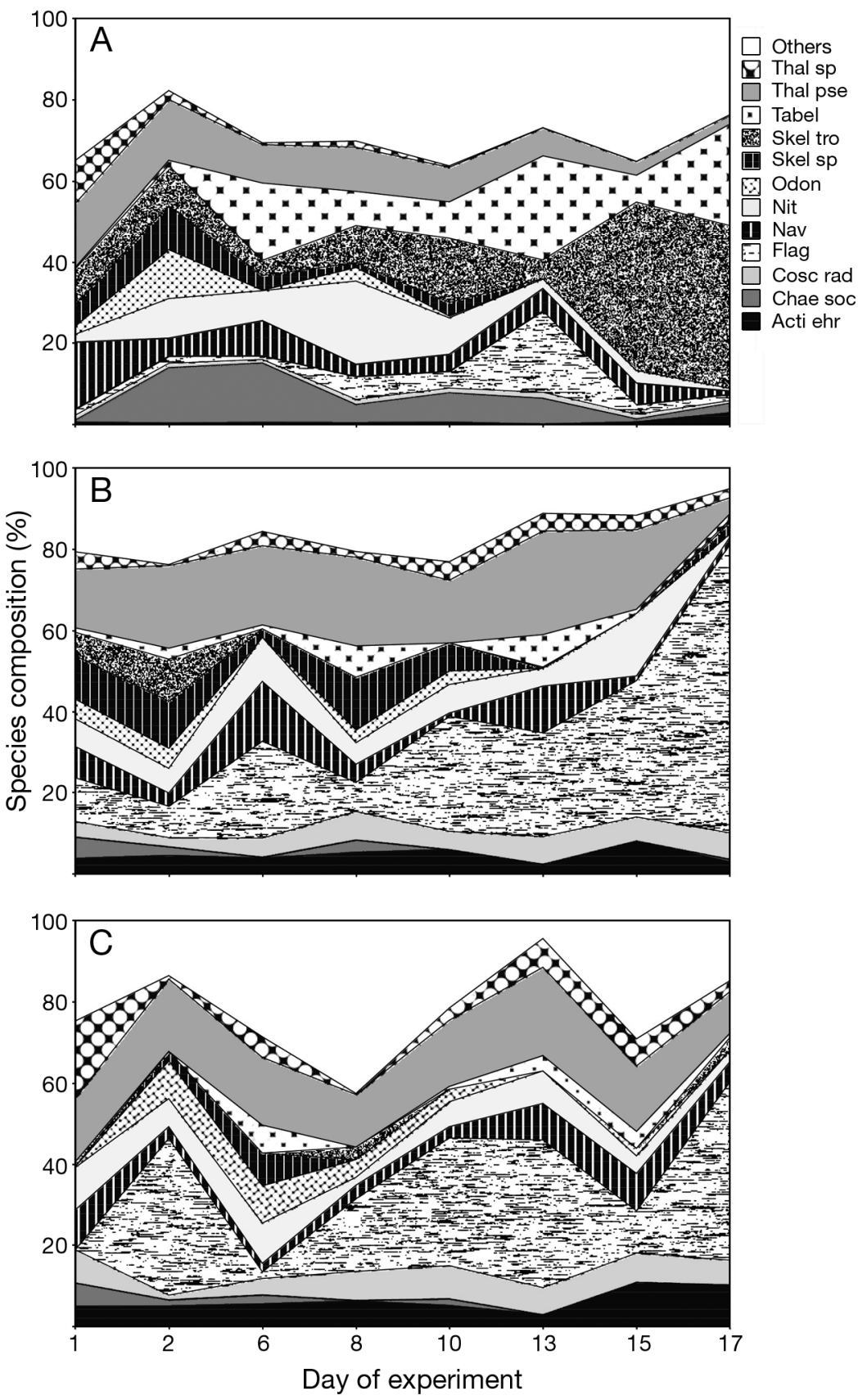

Fig. 2. Relative species composition in the inoculated mesocosms. Mean values are shown $(\mathrm{N}=3)$. (A) Plankton. (B) Plankton plus sediment. (C) Sediment. Thal $\mathrm{sp}=$ Thalassiosira sp., Thal pse $=$ Thalassiosira pseudonana, Tabel $=$ Tabellaria sp., Skel tro = Skeletonema tropicum, Skel sp = Skeletonema sp., Odon = Odontella sp., Nit = Nitzschia sp., Nav = Navicula sp., Flag = small $(<10 \mu \mathrm{m})$ unidentified flagellates, Cosc rad = Coscinodiscus radiatus, Chae soc $=$ Chaetoceros socialis, Acti ehr $=$ Actinocyclus ehrenbergii. Patterns shown in the legend correspond to the layers shown from top to bottom

Thalassiosira sp. was initially most abundant in the plankton mesocosms, whereas the abundances were much lower in the plankton-plus-sediment and the sediment-inoculated mesocosms (Fig. 3B). After Day 1, it rapidly declined in the plankton mesocosms. The highest record of Thalassiosira sp. abundances in the plankton-plus-sediment mesocosms occurred on Day 6 of the experiment. On Day 13, the highest abundances were recorded in the sediment mesocosms, which coincided with a second density peak in the planktonplus-sediment mesocosms.

Highest abundances of Skeletonema tropicum in the plankton and planktonplus-sediment mesocosms were recorded at the start of the experiment (Fig. 3C). The abundances in the sediment mesocosms were initially low, and remained low or below detection level throughout the experiment. After Day 1 (plankton mesocosms) and Day 3 of the experiment (plankton-plus-sediment mesocosms), the abundances of $S$. tropicum declined. On Days 15 to 17, higher abundances were again recorded in the plankton mesocosms.

Highest abundances of Skeletonema sp. were recorded on Day 1 of the experiment in the plankton-plus-sediment mesocosms and on Day 3 in the plankton mesocosms (Fig. 3D). Thereafter the density declined in the plankton and plankton-plus-sediment mesocosms; however, it was more rapid in the plankton mesocosms. The abundances of Skeletonema sp. in the sediment mesocosms was low or below detection level throughout the experiment.

Good growth of Chaetoceros socialis was only recorded in the plankton mesocosms (Fig. 3E), whereas the growth in the sediment and planktonplus-sediment mesocosms was poor. Initial cell densities were similar in the 3 treatments. After Day 1, the abundances in the plankton-plus-sediment and the sediment mesocosms were low or below detection level. The abun-

records in the sediment mesocosms. After Day 13, the abundances declined in all mesocosms, but the decline of T. pseudonana in the sediment mesocosms was more gradual. dances of $C$. socialis increased in the plankton mesocosms and reached a maximum on Day 6 of the experiment, but thereafter the abundances rapidly decreased also in the plankton mesocosms. 


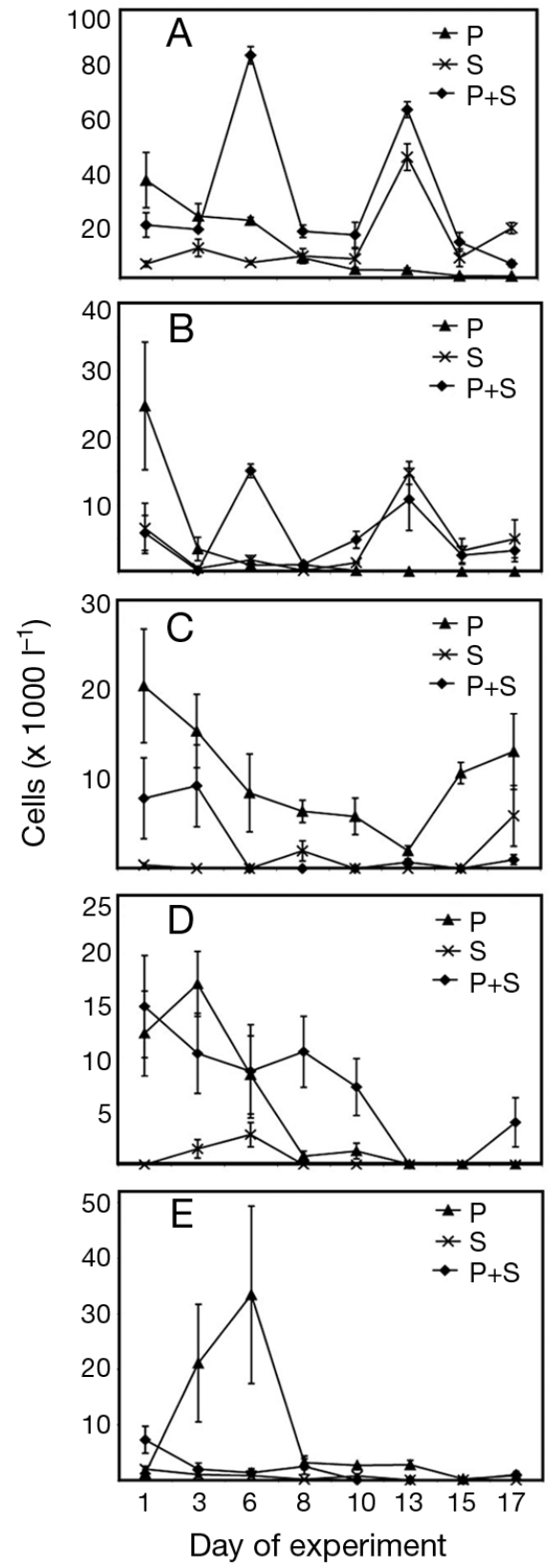

Fig. 3. Individual species succession of major diatom species in different inoculations. $\mathrm{P}=$ plankton, $\mathrm{P}+\mathrm{S}=$ plankton plus sediment, $\mathrm{S}=$ sediment. Symbols are mean $\pm \mathrm{SD}(\mathrm{N}=3)$. Note the different scales on the $y$-axes. (A) Thalassiosira pseudonana, (B) Thalassiosira sp., (C) Skeletonema tropicum, (D) Skeletonema sp., (E) Chaetoceros socialis

\section{Canonical correspondence analysis}

The CCA was significant ( $\mathrm{p}=0.005$, Monte Carlo). Eigenvalues of axes $1\left(\lambda_{1}=0.45\right), 2\left(\lambda_{2}=0.26\right), 3\left(\lambda_{3}=\right.$ $0.13)$, and $4\left(\lambda_{4}=0.11\right)$ explained $33.3 \%$ of the cumulative variance in species data, and $72.2 \%$ of the relationship between species and environmental data
(Table 2). The ranks of the environmental variables contributing to this model were (1) sediment, (2) $\mathrm{PO}_{4}$ (3) total bacteria, (4) chl a, (5) temperature, (6) salinity, (7) $\mathrm{O}_{2}$, (8) $\mathrm{pH}$, (9) plankton, (10) $\mathrm{TPC}$, (11) $\mathrm{NH}_{4}$, (12) $\mathrm{NO}_{3}$, and (13) $\mathrm{SiO}_{2}$. The CCA showed a high correlation between silicate and nitrate, and between temperature, salinity, and $\mathrm{pH}$, whereas the correlations between the other variables were moderate to low (Table 3). The values of the inflation factors (VIF) were low $(<7)$, except for total bacteria $(<10)$, and suggest that each one of the environmental parameters adds new information to the analysis. VIF is related to the multiple correlations among the environmental variables. The species-environmental correlations for axes 1 (0.94), 2 (0.91), 3 (0.93), and 4 (0.75) were high. On the basis of interset correlations, sediment had the strongest to axis 1, phosphate to axis 2, temperature to axis 3 , and oxygen to axis 4 (Table 2).

Inoculum type appears in the CCA biplot based on their species composition and association to the environmental variables (Fig. 4). The length of the environmental arrows and their orientation on the biplot indicate their relative importance to each axis. Environmental arrows represent a gradient, where the mean value is located at the origin, and the arrow points in the direction of its increase.

The affinity of the major taxa in relation to inoculum and environmental variables differed. Thalassiosira pseudonana and Thalassiosira sp. were abundant in both inocula and thus are located near the center of the biplot (Fig. 4). Skeletonema tropicum and Skeletonema sp. had a high affinity to the plankton-inoculated mesocosms. S. tropicum displayed a relatively higher affinity than Skeletonema sp. A majority of all Chaetoceros species were located on the right side of the biplot, and thus were more common in the plankton-

Table 2. Interset correlations of environmental variables with axes. $\lambda$ : eigenvalue for each axis; TPC: total plate count

\begin{tabular}{|lcccc|}
\hline Variable & Axis 1 & Axis 2 & Axis 3 & Axis 4 \\
& $\left(\lambda_{1}=0.45\right)$ & $\left(\lambda_{2}=0.26\right)$ & $\left(\lambda_{3}=0.13\right)$ & $\left(\lambda_{4}=0.11\right)$ \\
\hline $\mathrm{Chl} a$ & -0.613 & -0.147 & -0.209 & 0.281 \\
$\mathrm{PO}_{4}$ & -0.524 & 0.534 & -0.148 & 0.041 \\
$\mathrm{NH}_{4}$ & -0.107 & 0.359 & -0.368 & 0.042 \\
$\mathrm{NO}_{3}$ & 0.254 & 0.179 & -0.294 & 0.228 \\
$\mathrm{SiO}_{2}$ & -0.036 & -0.065 & 0.256 & -0.023 \\
$\mathrm{O}_{2}$ & 0.294 & 0.055 & -0.334 & 0.441 \\
$\mathrm{Salinity}$ & -0.24 & 0.296 & 0.415 & -0.366 \\
pH & -0.084 & 0.428 & -0.206 & -0.21 \\
Temperature & 0.192 & -0.376 & 0.586 & -0.262 \\
Total bacteria & -0.642 & -0.032 & -0.303 & 0.256 \\
$\mathrm{TPC}$ & -0.271 & 0.364 & 0.104 & -0.019 \\
Plankton & 0.341 & -0.089 & -0.19 & -0.106 \\
Sediment & -0.845 & -0.077 & -0.075 & 0.201 \\
\hline
\end{tabular}


Table 3. Correlation among environmental and nominal variables (plankton and sediment) used in canonical correspondence analysis (CCA)

\begin{tabular}{|c|c|c|c|c|c|c|c|c|c|c|c|c|c|}
\hline Variable & Chl a & $\mathrm{PO}_{4}$ & $\mathrm{NH}_{4}$ & $\mathrm{NO}_{3}$ & $\mathrm{SiO}_{2}$ & $\mathrm{O}_{2}$ & Salinity & $\mathrm{pH}$ & Temp. & $\begin{array}{c}\text { Total } \\
\text { bacteria }\end{array}$ & TPC & Plankton & Sediment \\
\hline Chl a & 1.00 & & & & & & & & & & & & \\
\hline $\mathrm{PO}_{4}$ & 0.32 & 1.00 & & & & & & & & & & & \\
\hline $\mathrm{NH}_{4}$ & -0.09 & 0.07 & 1.00 & & & & & & & & & & \\
\hline $\mathrm{NO}_{3}$ & -0.09 & -0.26 & 0.62 & 1.00 & & & & & & & & & \\
\hline $\mathrm{SiO}_{2}$ & -0.10 & -0.32 & 0.55 & 0.90 & 1.00 & & & & & & & & \\
\hline $\mathrm{O}_{2}$ & 0.16 & -0.38 & 0.07 & 0.29 & 0.23 & 1.00 & & & & & & & \\
\hline Salinity & 0.01 & -0.53 & 0.34 & 0.51 & 0.52 & 0.37 & 1.00 & & & & & & \\
\hline $\mathrm{pH}$ & 0.03 & -0.54 & 0.34 & 0.52 & 0.53 & 0.41 & 1.00 & 1.00 & & & & & \\
\hline Temp. & 0.02 & -0.56 & 0.32 & 0.50 & 0.52 & 0.40 & 1.00 & 1.00 & 1.00 & & & & \\
\hline Total bacteria & 0.06 & 0.33 & 0.00 & 0.07 & 0.07 & 0.27 & -0.02 & 0.00 & -0.01 & 1.00 & & & \\
\hline $\mathrm{TPC}$ & 0.01 & 0.39 & 0.19 & -0.13 & -0.17 & -0.37 & -0.12 & -0.15 & -0.16 & -0.13 & 1.00 & & \\
\hline Plankton & -0.02 & -0.31 & 0.05 & 0.22 & 0.19 & 0.33 & 0.17 & 0.18 & 0.19 & -0.05 & -0.47 & 1.00 & \\
\hline Sediment & 0.49 & 0.46 & -0.07 & -0.13 & -0.06 & -0.11 & -0.21 & -0.21 & -0.22 & 0.78 & 0.12 & -0.37 & 1.00 \\
\hline
\end{tabular}

inoculated mesocosms, even though many species of this genus have resting stages, and some of these were abundant in the sediment used as inoculum. Chaetoceros lorenzianus was an exception and appeared on the left side of the biplot, and was thus associated to the sediment inocula. Pseudo-nitzschia spp., a genus not known to form resting stages, was common in the plankton-inoculated mesocosms. Bacteriastrum furcatum, B. hyalinum, Ditylum brightwelli, Leptocylindrus danicus, and L. minimus were located on the right side of the biplot and had a high affinity to planktoninoculated mesocosms, in spite of having previously documented resting stages. Several dinoflagellate species were found in the sediment mesocosms but all had low abundances. Other environmental variables appeared not to influence the frequency of the major species groups.

The arrow representing chl a concentration was closely associated with the arrow representing sediment inocula (Fig. 4). This is also illustrated in Fig. 1A, where chl a concentrations in the sediment mesocosms were high early in the experiment. The location on the left side of the biplot of large cells with many chloroplasts, such as Coscinodiscus spp., is a consequence of the environmental variable chl a (Fig. 4).

\section{DISCUSSION}

The present study demonstrated the importance of benthic resting stages in seeding the planktonic population and showed that the type of inoculum influences the development and the taxonomic composition of the phytoplankton community. The most significant effects of the inoculum types were the timing of the bloom and differences in species proportions. To our knowledge, no mesocosm studies on naturally occurring phytoplankton communities and their development have been performed along the SW coast of India before. The contribution of resting stages to phytoplankton blooms in the tropics is poorly investigated, but this study showed that resuspended resting stages are important for phytoplankton bloom dynamics in the area.

The onset of phytoplankton growth lagged behind in the sediment mesocosms compared to the planktoninoculated mesocosms. This was a consequence of 2 different seeding strategies: (1) proliferation of vegetative cells originating from the plankton attaining exponential growth soon after inoculation, and (2) later germinated resting stages and subsequent growth. This is in accordance with a previous microcosm experiment in Scandinavia, where bloom development also was faster in plankton-inoculated microcosms (McQuoid \& Godhe 2004). Diatom resting stages have no dormancy period, as is common among dinoflagellate cysts. However, they may show a 1 to $8 \mathrm{~d}$ lag period of growth compared to vegetative cells, which can grow almost immediately (Itakura et al. 1997, Kuwata \& Takahashi 1999), which may then influence the timing of bloom development. Previous mesocosm experiments have shown that the size of the inoculum is also an important aspect in time required for bloom development (Pitcher et al. 1993, McQuoid \& Godhe 2004). Diatom resting stages are generally less common in the tropics (Hargraves \& French 1983), and moreover, the low dinoflagellate cyst abundances found in the study area (Godhe et al. 2000, 2002b) indicate that benthic resting stages in general may be less abundant compared to temperate waters. From this, it follows that the sediment inoculum contains fewer resting stages, and thus the lag period is prolonged. 


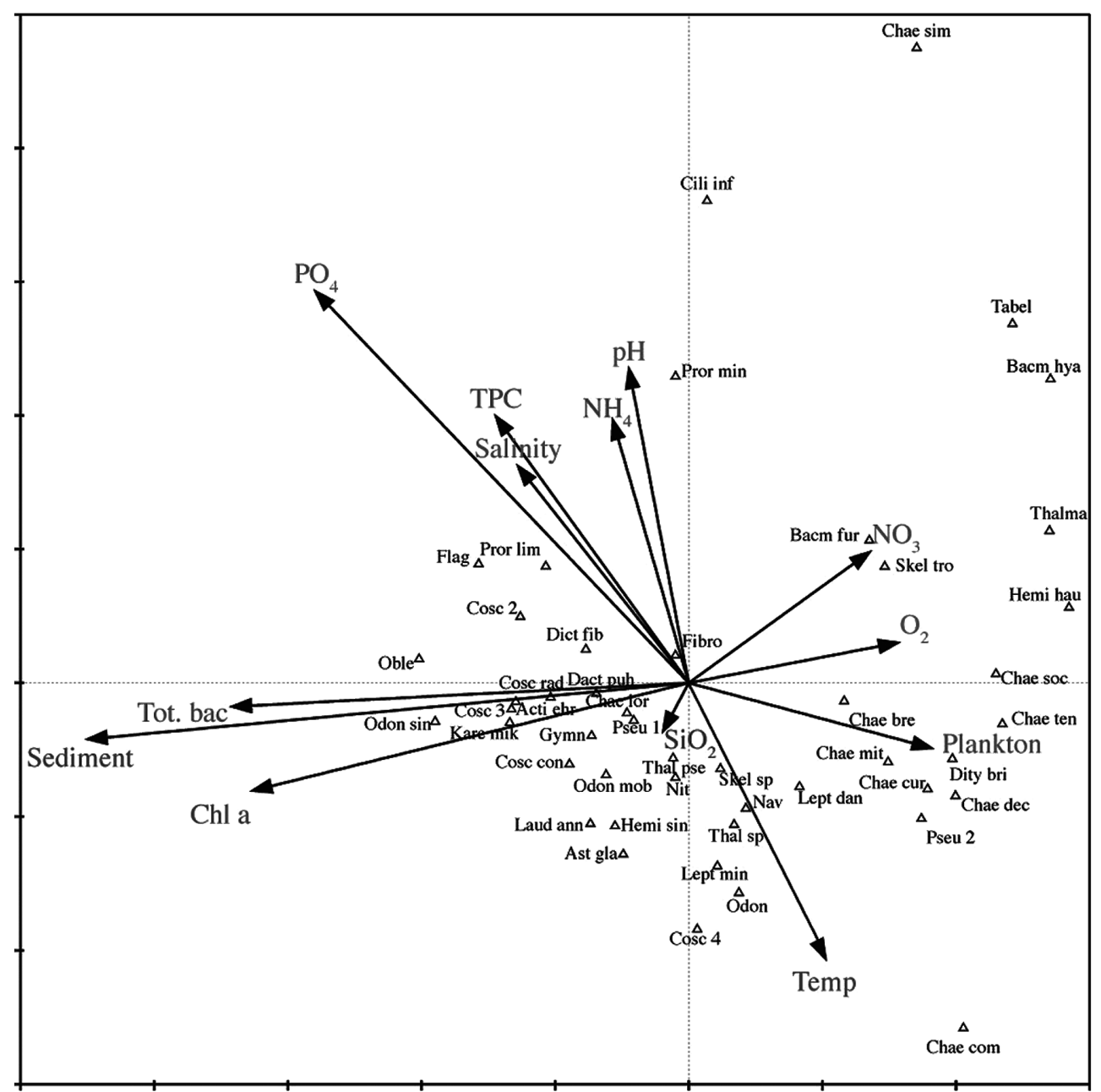

Fig. 4. Canonical correspondence analysis (CCA) biplots for species abundance in mesocosms and environmental variables. Acti ehr = Actionocyclus ehrenbergii, Ast gla = Asterionellopsis glacialis, Bacm fur = Bacteriastrum furcatum, Bacm hya $=$ Bacteriastrum hyalinum, Chae bre = Chaetoceros brevis, Chae com = Chaetoceros compressus, Chae cur $=$ Chaetoceros curvicetus, Chae dec $=$ Chaetoceros decipiens, Chae lor = Chaetoceros lorenzianus, Chae mit = Chaetoceros mitra, Chae sim = Chaetoceros simplex, Chae $\mathrm{soc}=$ Chaetoceros socialis, Chae ten $=$ Chaetoceros tenuissimus, Cili inf $=$ Ciliophrys infusionum, Cosc $2=$ Coscinodiscus sp. 2 , Cosc $3=$ Coscinodiscus sp. 3, Cosc $4=$ Coscinodiscus sp. 4, Cosc con = Coscinodiscus concinnus, Cosc rad = Coscinodiscus radiatus, Dact puh $=$ Dactyliosolen phuketensis, Dict fib = Dictyocha fibula, Dity bri $=$ Ditylum brightwelli, Fibro = Fibrocapsa sp., Flag $=$ unidentified flagellates, Gymn = Gymnodinium sp., Hemi hau = Hemiaulus haukii, Hemi sin = Hemiaulus sinensis, Kare mik $=$ Karenina mikimotoi, Laud ann = Lauderia annulata, Lept dan = Leptocylindrus danicus, Lept min = Leptocylindrus minimus, Nav = Navicula sp., Nit = Nitzschia sp., Oble = Oblea sp., Odon = Odontella sp., Odon mob = Odontella mobiliensis, Odon sin $=$ Odontella sinensis, Pror lim = Prorocentrum lima, Pror min = Prorocentrum minimum, Pseu 1 = Pseudo-nitzschia sp. 1, Pseu 2 = Pseudo-nitzschia sp. 2, Skel sp = Skeletonema sp., Skel tro = Skeletonema tropicum, Tabel = Tabellaria sp., Thalma = Thalassionema nitzschioides,

Thal pse $=$ Thalassiosira pseudonana, Thal $\mathrm{sp}=$ Thalassiosira $\mathrm{sp}$.

The composition of the dominant species was similar in the different treatments, but their relative proportions changed over time with respect to the different inocula. Several species showed strong association with a particular inoculum type, which highlighted the importance of the inoculum in influencing the taxonomic composition of the plankton community. A microcosm study with different types of inocula previously performed in Scandinavia also showed different species compositions when seeded from benthos or plankton (McQuoid \& Godhe 2004). Moreover, similar species composition in the sediment inocula and the different mesocosms indicates that the benthic resting stages seed populations of autochthonous species in the water column, and introduced species are of minor importance. Analogous patterns are supported by several studies in temperate waters, where similar species composition was found in sediment and plankton. The 
diatom resting stages in the sediment were recorded throughout the year, and seasonal cycles of diatom species in the plankton indicated autochthonous seeding (Pitcher 1990, Itakura et al. 1997).

Most mesocosm studies focus on one or just a few species (e.g. Brussaard et al. 2005, Patel et al. 2005), and how varying parameters affect their growth. Studies focusing on bloom development and succession within the natural phytoplankton community are less common, but these multi-species studies show that one or just a few species become dominant shortly after the initiation of the experiments (e.g. Alldrege et al. 1995, McQuoid \& Godhe 2004). In the present study, the species diversity was maintained throughout the experiment, although the diversity in all inocula types decreased towards the end. This is probably a consequence of the fact that the natural phytoplankton community in the tropics generally displays high species diversity, and that single-species phytoplankton blooms rarely occurs (Subrahmanyan \& Sarma 1960, Irigoien et al. 2004). Generally the chl a concentrations of all the mesocosms were low $\left(<3 \mu \mathrm{g} \mathrm{l}^{-1}\right)$ in our study, which are normal conditions in the coastal Arabian Sea during December and January (Chaturvedi 2005). Low chl a values can be a result of high diversity since exclusive competition will be less (Duarte et al. 2006), which is in accordance with the overall results from our study.

Diatoms may employ a variety of seeding strategies for initiation of planktonic growth. Our results suggest that the strategies differ among species, which is reflected in the strong association of specific species to inocula type in the CCA. Moreover, our results further indicate that the one species may use the same, e.g. Thalassiosira pseudonana, or different, e.g. Chaetoceros socialis and Skeletonema sp., strategies in different parts of the world. Species belonging to the genus Thalassiosira are adapted to varying environments, and are dominant in both water column and surface sediment (Pedersen et al. 2005, Kasim \& Mukai 2006). The resting stages contribute extensively by seeding the plankton in temperate waters (Itakura et al. 1997, McQuoid et al. 2002, Ishikawa \& Furuya 2004). In Indian waters, Mitbavkar \& Anil (2002) recorded vegetative cells of Thalassiosira in cultures established from sediment slurries. In our study, Thalassiosira declined in the plankton mesocosms, while in the planktonplus-sediment mesocosms, 2 cell density peaks were observed. The last peak coincided with the highest recorded abundances in the sediment mesocosms, which indicates recruitment of resting stages from the sediment. Resting stages of Skeletonema are very successful in seeding blooms in temperate water (Itakura et al. 1997, McQuoid \& Godhe 2004), but our experiment indicates that in coastal SW India, propagation by resting stages is not important. We recorded no resting stages in the sediment inoculum, and observed virtually no growth in the sediment mesoscosms. Blooms of Thalassiosira have been recorded to be succeeded by blooms of Chaetoceros socialis (Booth et al. 2002). A similar scenario was recorded in the plankton mesocosms in our study. Resting stages of $C$. brevis, $C$. didymus, and Chaetoceros sp. were recorded in the sediment inoculum, but had no noticeable contribution to the vegetative community in the sediment mesocosms. The suggested explanation for these contradicting results is that germination of Chaetoceros spp. spores in the tropics might be triggered by some seasonal cue (McQuoid \& Hobson 1996), although continuous germination of spores from the same genus have been recorded from temperate waters (Itakura et al. 1997).

In the present study, the steady concentration of silicate and nitrate despite diatom dominance in the mesocosms is puzzling. This can be explained by the low bacterial concentrations and the increased growth of flagellates with time. The low bacterial abundances suggest a significant predation by bacterivorous flagellates, which leads to remineralization of major nutrients (Azam et al. 1983). In addition, the nutrient concentrations can probably support much higher phytoplankton cell abundances, but the great species diversity recorded in all mesocosms will prevent any monospecific bloom, which is required to attain high cell abundance and subsequent nutrient depletion.

Unidentified small $(<10 \mu \mathrm{m})$ flagellates increased towards the end of the experiment. Ciliates were the only potential predators on diatoms recorded in the mesocosms, but the proportions of these were low all through the study, ranging from $0.3 \%$ of the total abundance at the onset of the experiment to a maximum of $1.7 \%$. This phenomenon, i.e. a shift from an autotrophic- to a heterotrophic-dominated community, is commonly observed in enclosures with small volume relative to its large surfaces. This is related to a variety of 'wall-effects' that can change the species composition (Chen \& Kemp 2004). Another commonly observed artefact in mesocosms is the proliferation of benthic diatoms, mainly pennates, which are not regular members of the phytoplankton community (M. R. McQuoid \& A. Godhe unpubl.). In that experiment, Nitzschia sp. and Navicula sp. were common but in similar proportions irrespective of mesocosm types. Limiting the mesocosm experimental time can minimize these type of artefacts. In our experimental system, we could see a shift from an autotrophicdominated to a heterotrophic community, and therefore the experiment was terminated.

$\mathrm{Chl} a$ in the sediment mesocosms reached its highest concentrations early during our experiment, whereas 
the biovolume and the abundances of diatom cells in the same mesocosms were relatively low. Presence of large cells such as Coscinodiscus spp. were recorded in the Lugol's fixed samples from the sediment mesocosms, and might have contributed to the observed rise in chl a concentrations. Further, since many of these large cells were partially damaged and only actively growing cells were counted, they had no contribution to the estimated biovolume or total abundance of living diatom cells, but probably influenced the high initial chl a concentrations (Fig. 1A). Also, the sediment mesocosms had in general higher abundance of cyanobacteria, which also can be a factor in raising the initial concentration of chl a. However, due to the small volume of cyanobacteria, their effect on the total biovolume was minor.

Total cell abundances were comparable in all inoculated mesocosms, despite lower light penetration in the sediment-inoculated mesocosms. Accordingly, the phytoplankton growth in the plankton mesocosms was not assumed to be favored by better light conditions. Light conditions in standard operating protocols for diatom germination and subsequent growth are set to 40-50 $\mu \mathrm{mol}$ photons $\mathrm{m}^{-2} \mathrm{~s}^{-1}$ (Itakura et al. 1997, Kuwata \& Takahashi 1999), comparable to the light provided in all mesocosms.

Although diatom resting stage formation is less common in tropical upwelling waters where nutrients are not often depleted (Hargraves \& French 1983), our study has shown that resting stages may contribute significantly to the phytoplankton community of the SW coast of India. Formation of resting stages is often seasonal, and a rapid change of hydrographic conditions (nutrients, temperature, $\mathrm{pH}$, salinity, or light) is required for the induction of diatom resting stages (McQuoid \& Hobson 1996). Moreover, resting stages are, under natural conditions, often formed during or following periods of maximum vegetative division (Garrison 1981). Considering the annual variation in hydrographic parameters and phytoplankton biomass of the area we studied, the post-bloom conditions in August with reduced inorganic nutrients of the water column (Subrahmanyan \& Sarma 1960) would constitute the most plausible time for diatom resting stage formation in the SE coastal Arabian Sea.

The resting stage is thought to mainly serve as longterm survival, and therefore might be scarce in the tropics. Laboratory experiments have documented prolonged survival of diatom resting stages in cool (5 to $15^{\circ} \mathrm{C}$ ) conditions (Itakura et al. 1997). Bottom sea water temperature in the SE coastal Arabian Sea is $>25^{\circ} \mathrm{C}$ (Subrahmanyan \& Sarma 1960), and perhaps the resting stages do not survive as long as in temperate waters. However, functions other than long-term survival have also been suggested. Resting stages could serve as a short-term survival strategy between intermittent blooms (Garrison 1981), and germination of distinct genetic clones adapted to different environmental settings could ensure species survival in unfavorable environments (Rynearson et al. 2006).

The germination of diatom resting stages is believed to be most affected by light (French \& Hargraves 1985). The Secchi depth at coastal Mangalore is approximately $5 \mathrm{~m}$, due to high turbidity, and therefore resuspension is required for germination. Tidal force is strong and is felt up to the $10 \mathrm{~m}$ depth contour, which corresponds to ca. $2 \mathrm{~km}$ from the shore (Segar \& Hariharan 1989). The tidal currents could thus continuously seed the water column with resuspended resting stages, at least in the shallower parts. Most probably the strong SW monsoon, which induces upwelling along the coast, is the most important factor for resuspension, germination, and subsequent vegetative diatom growth from deeper areas. Primary production and diatom abundances are also known to be highest during this period of the year (Subrahmanyan \& Sarma 1960). Benthic germination can be regulated by seasonal factors (McQuoid \& Hobson 1996, Eilertsen \& Wyatt 2000), and thus, diatoms in the region could be tuned for germination during SW monsoon upwelling.

The results from this study further confirm that benthic resting stages contribute by seeding the water column. Despite a presumed low density of benthic resting stages in tropical sediments, they can influence the phytoplankton community in the water column. Our results indicate that species composition can be altered if a population is seeded by resting stages or by planktonic cells.

Acknowledgements. This study was financed by Sida (SWE 2004-129) and Formas-Sida (2005-255). It was also supported by the Kapten Carl Stenholms donationsfond, Magnus Bergvalls Stiftelse (MBS), and the Oscar and Lili Lamms Foundation. We thank $\AA$. Lindskog, who helped with the laboratory work as part of her Master thesis, and Dr. P. K. Krishnakumar at the CMFRI in Mangalore for logistic support. Three anonymous reviewers are acknowledged for their constructive comments on the manuscript.

\section{LITERATURE CITED}

Alldrege AL, Gotschalk C, Passow U, Riebesell U (1995) Mass aggregation of diatom blooms: insights from a mesocosm study. Deep-Sea Res II 42:9-27

Azam F, Fenchel T, Field JG, Gray JS, Meyer-Reil LA, Thingstad F (1983) The ecological role of water-column microbes in the sea. Mar Ecol Prog Ser 10:257-263

Backhaus JO, Wehde EN, Hegseth EN, Kämpf J (1999) Phytoplankton convection: the role of oceanic convection in primary production. Mar Ecol Prog Ser 189:77-92

Backhaus JO, Hegseth EN, Wehde H, Irigoien X, Hatten K, Logemann K (2003) Convection and primary production in winter. Mar Ecol Prog Ser 251:1-14 
Booth BC, Larouche P, Bélanger S, Klein B, Amiel D, Mei ZP (2002) Dynamics of Chaetoceros socialis blooms in the North Water. Deep-Sea Res II 49:5003-5025

Brussaard CPD, Kuipers B, Veldhuis MJW (2005) A mesocosm study of Phaeocystis globosa population dynamics I. Regulatory role of viruses in bloom control. Harmful Algae 4: 859-874

Chaturvedi N (2005) Variability of chlorophyll concentration in the Arabian Sea and Bay of Bengal as observed from SeaWiFS data from 1997-2000 and its interrelationship with Sea Surface Temperature (SST) derived from NOAA AVHRR. Int J Remote Sens 26:3695-3706

Chen CC, Kemp WM (2004) Periphyton communities in experimental marine ecosystems: scaling the effect of removal from container walls. Mar Ecol Prog Ser 271: $27-41$

Cook D, DePaola A, McCarthy S (2000) Direct plating procedure for the enumeration of total and pathogenic Vibrio parahaemolyticus in oyster meats. US Food and Drug Administration (FDA), Office of Seafood, Gulf Seafood Laboratory, Dauphin Island, AL

D'Souza F, Garg A, Bhosle NB (2003) Biogeochemical characteristics of sedimenting particles in Dona Paula Bay, India. Estuar Coast Shelf Sci 58:311-320

Duarte P, Macedo MF, da Fonseca LC (2006) The relationship between phytoplankton diversity and community function in a coastal lagoon. Hydrobiologia 555:3-18

Eilertsen H, Wyatt T (2000) Phytoplankton models and life history strategies. S Afr J Mar Sci 22:323-338

French FW, Hargraves P (1985) Spore formation in the life cycles of the diatoms Chaetoceros diadema and Leptocylindrus danicus. J Phycol 21:477-483

Garrison DL (1981) Monterey Bay phytoplankton I. Resting spore cycles of phytoplankton assemblages. J Plankton Res 3:137-156

Godhe A, Karunasagar I, Karunasagar I, Karlson B (2000) Dinoflagellate cysts in recent marine sediments from SW India. Bot Mar 43:39-48

Godhe A, Svensson S, Rehnstam-Holm AS (2002a) Oceanographic settings explain fluctuations in Dinophysis spp. and concentrations of diarrhetic shellfish toxin in the plankton community within a mussel farm area on the Swedish west coast. Mar Ecol Prog Ser 240: 71-83

Godhe A, Rehnstam-Holm AS, Karunasagar I, Karunasagar I (2002b) PCR detection of dinoflagellate cysts in field sediment samples from tropic and temperate environments. Harmful Algae 1:361-373

Hallegraeff GM, Bolch CJ (1992) Transport of diatom and dinoflagellate resting spores in ships' ballast water: implications for plankton biogeography and aquaculture. J Plankton Res 14:1067-1084

Hargraves PE, French FW (1983) Diatom resting spores: significance and strategies. In: Fryxell GA (ed) Survival strategies of the algae. Cambridge University Press, Cambridge, p 49-68

Hasle G, Syvertsen E (1996) Marine diatoms. In: Tomas C (ed) Identifying marine diatoms and dinoflagellates. Academic Press, San Diego, CA, p 5-385

Irigoien X, Huisman J, Harris RP (2004) Global biodiversity patterns of marine phytoplankton and zooplankton. Nature 429:863-867

Ishikawa A, Furuya K (2004) The role of diatom resting stages in the onset of the spring bloom in the East China Sea. Mar Biol 145:633-639

Itakura S, Imai I, Itoh K (1997) 'Seed bank' of coastal planktonic diatoms in bottom sediments of Hiroshima Bay, Seto Inland Sea, Japan. Mar Biol 128:497-508
Kasim M, Mukai H (2006) Contribution of benthic and epiphytic diatoms to clam and oyster production in the Akkeshi-ko estuary. J Oceanogr 62:267-281

Kilham P, Kilham SS (1980) The evolutionary ecology of phytoplankton. In: Morris I (ed) The physiological ecology of phytoplankton. Blackwell, Boston, MA, p 571-597

Krishnakumar PK, Bhat GS (2007) Seasonal and interannual variations of oceanographic conditions off Mangalore coast (Karnataka, India) in the Malabar upwelling system during 1995-2004 and their influences on pelagic fishery. Fish Oceanogr (in press)

Kuwata A, Takahashi M (1999) Survival of resting spores and resting cells of the marine planktonic diatom Chaetoceros pseudocurvicetus under fluctuating nitrate conditions. Mar Biol 134:471-478

Lundholm N, Daubjerg N, Moestrup Ø (2002) Phylogeny of the Bacillariaceae with emphasis on the genus Pseudonitzschia (Bacillariophyceae) based on partial LSU rDNA. Eur J Phycol 37:115-134

McQuoid M, Godhe A (2004) Recruitment of coastal planktonic diatoms from benthic versus pelagic cells: variation in bloom development and species composition. Limnol Oceanogr 49:1123-1133

McQuoid M, Hobson L (1996) Diatom resting stages. J Phycol 32:889-902

McQuoid MR, Godhe A, Nordberg K (2002) Viability of phytoplankton resting stages in the sediments of a coastal Swedish fjord. Eur J Phycol 37:191-201

Mitbavkar S, Anil AC (2002) Diatoms of the microphytobenthic community: population structure in a tropical intertidal sand flat. Mar Biol 140:41-57

Parsons T, Maita Y, Lalli C (1984) A manual of chemical and biological methods for seawater analysis. Pergamon, Oxford

Patel D, Thake B, Thornton DCO (2005) Effect of light and turbulent mixing on the growth of Skeletonema costatum (Bacillariophyceae). Mar Biol 146:633-644

Pedersen SA, Ribergaard MH, Simonsen CS (2005) Microand mesozooplankton in southwest Greenland waters in relation to environmental factors. J Mar Syst 56:85-112

Pitcher G (1990) Phytoplankton seed populations of the Cape Peninsula upwelling plume, with particular reference to resting spores of Chaetoceros (Bacillariophyceae) and their role in seeding upwelling waters. Estuar Coast Shelf Sci 31: 283-301

Pitcher G, Bolton J, Brown P, Hutchings L (1993) The development of phytoplankton blooms in upwelled waters of the southern Benguela upwelling system as determined by microcosm experiment. J Exp Mar Biol Ecol 165: $171-189$

Porter K, Feig Y (1980) The use of DAPI for identifying and counting aquatic microflora. Limnol Oceanogr 25:943-948

Raffaelli D, Bell E, Weithoff G, Matsumoto A and 5 others (2003) The ups and downs of benthic ecology: considerations of scale, heterogeneity and surveillance for benthic-pelagic coupling. J Exp Mar Biol Ecol 285-286: 191-203

Ramana TV, Nathaniel DE, Reddy PM (1991) Distribution of some oceanographic factors in the Arabian Sea off Manjeswar and theoretic possible effect on oilsardine and mackerel fisheries in the area. J Mar Biol Assoc India 33:9-18

Rixen T, Haake B, Ittekkot V (2000) Sedimentation in the western Arabian Sea: the role of coastal and open-ocean upwelling. Deep-Sea Res II 47:2155-2178

Rynearson T, Newton J, Armbrust A (2006) Spring bloom development, genetic variation, and population succession in the planktonic diatom Ditylum brightwelli. Limnol Oceanogr 51:1249-1261 
Sarno D, Kooistra W, Medlin L, Percopo I, Zingone A (2005) Diversity in the genus Skeletonema (Bacillariophyceae). II. An assessment of the taxonomy of $S$. costatum-like species with the description of four new species. J Phycol 41: 151-176

Segar K, Hariharan V (1989) Seasonal distribution of nitrate, nitrite, ammonium and plankton in effluent discharge area off Mangalore, west coast of India. Indian J Mar Sci 18: 170-173

Shenoy DM, Patil JS (2002) Temporal variations in dimethylsulphoniopropionate and dimethyl sulphide in the Zuari estuary, Goa (India). Mar Environ Res 56:387-402

Sicko-Goad L, Stoermer E, Kociolek J (1989) Diatom resting cell rejuventaion and formation: time course, species records and distribution. J Plankton Res 11:375-389

Smayda TJ (2002) Turbulence, watermass stratification and harmful algal blooms: an alternative view and frontal zones as 'pelagic seed banks'. Harmful Algae 1:95-112

Subrahmanyan R (1958) Ecological studies on the marine phytoplankton on the west coast of India. Mem Indian Bot Soc 1:145-151

Subrahmanyan R (1959) Studies on the phytoplankton of the west coast of India. Proc Indian Acad Sci 50:113-252

Subrahmanyan R (1960) Observation on the effect of the monsoon in the production of phytoplankton. J Indian Bot Soc 39:78-89

Subrahmanyan R, Sarma AHV (1960) Studies on the phytoplankton of the west coast of India. III. Seasonal variation

Editorial responsibility: Alain Vézina (Contributing Editor), Dartmouth, Nova Scotia, Canada of the phytoplankton and the environmental factors. Indian J Fish 7:307-336

Subrahmanyan R, Sarma AHV (1965) Studies on the phytoplankton of the west coast of India. IV. Magnitude of the standing crop for 1955-1962, with observations on nanoplankton and its significance to fisheries. J Mar Biol Assoc India 7:406-419

Sun J, Liu D (2003) Geometric models for calculating cell biovolume and surface area for phytoplankton. J Plankton Res 25:1331-1346

ter Braak CJF, Smilauer P (2002) CANOCO reference manual and CanoDraw for Windows user's guide: software for canonical community ordination (version 4.5). Microcomputer Power, Ithaca, NY

Thomsen HA (ed) (1992) Plankton i de inre danske farvande, Vol 11. Dansk Miljøstyrelse, Copenhagen (in Danish)

Throndsen J, Hasle G, Tangen K (2003) Norsk kystplanktonflora. Almater Forlag, Oslo (in Norwegian)

Tomas C (1997) Identifying marine phytoplankton. Academic Press, San Diego, CA

Tommasa LD, Belmonte G, Palanques A, Pugi P (2000) Resting stages in a submarine canyon: a comparison of shallow-deep-sea coupling? Hydrobiologia 440: $249-260$

Utermöhl H (1958) Zur Vervollkommnung der quantitativen Phytoplankton-Methodik. Mitt Int Ver Limnol 9:1-38 (in German)

Submitted: October 27, 2006; Accepted: May 9, 2007

Proofs received from author(s): September 11, 2007 